\title{
Intakes and sources of isoflavones, lignans, enterolignans, coumestrol and soya-containing foods in the Norfolk arm of the European Prospective Investigation into Cancer and Nutrition (EPIC-Norfolk), from $7 \mathrm{~d}$ food diaries, using a newly updated database
}

\author{
Angela A Mulligan ${ }^{1, *}$, Gunter GC Kuhnle², Marleen AH Lentjes', \\ Veronica van Scheltinga ${ }^{1}$, Natasha A Powell ${ }^{1}$, Alison McTaggart ${ }^{1}$, \\ Amit Bhaniani ${ }^{1}$ and Kay-Tee Khaw ${ }^{1,3}$ \\ ${ }^{1}$ European Prospective Investigation of Cancer, Department of Public Health and Primary Care, University of \\ Cambridge, Strangeways Research Laboratory, Worts Causeway, Cambridge CB1 8RN, UK: ${ }^{2}$ Department of \\ Food and Nutritional Sciences, University of Reading, Reading, UK: ${ }^{3}$ EPIC, Department of Gerontology, \\ Addenbrooke's Hospital, School of Clinical Medicine, University of Cambridge, Cambridge, UK
}

Submitted 27 March 2012: Final revision received 27 June 2012: Accepted 5 July 2012: First published online 3 September 2012

\begin{abstract}
Objective: A diet rich in phyto-oestrogens has been suggested to protect against a variety of common diseases but UK intake data on phyto-oestrogens or their food sources are sparse. The present study estimates the average intakes of isoflavones, lignans, enterolignans and coumestrol from $7 \mathrm{~d}$ food diaries and provides data on total isoflavone, lignan and phyto-oestrogen consumption by food group.

Design: Development of a food composition database for twelve phyto-oestrogens and analysis of soya food and phyto-oestrogen consumption in a populationbased study.

Setting: Men and women, aged 40-79 years, from the general population participating in the Norfolk arm of the European Prospective Investigation into Cancer and Nutrition (EPIC-Norfolk) between 1993 and 1997, with nutrient and food data from $7 \mathrm{~d}$ food diaries.

Subjects: A subset of 20437 participants.

Results: The median daily phyto-oestrogen intake for all men was $1199 \mu \mathrm{g}$ (interquartile range 934-1537 $\mu \mathrm{g}$; mean $1504 \mu \mathrm{g}$, SD $1502 \mu \mathrm{g}$ ) and $888 \mu \mathrm{g}$ for all women (interquartile range $710-1135 \mu \mathrm{g}$; mean $1205 \mu \mathrm{g}$, SD $1701 \mu \mathrm{g}$ ). In soya consumers, median daily intakes were higher: $2861 \mu \mathrm{g}$ in men (interquartile range 1304-7269 $\mu \mathrm{g}$; mean $5051 \mu \mathrm{g}$, SD $5031 \mu \mathrm{g}$ ) and $3142 \mu \mathrm{g}$ in women (interquartile range 1089-7327 $\mathrm{g}$; mean $5396 \mu \mathrm{g}$, SD $6092 \mu \mathrm{g}$ ). In both men and women, bread made the greatest contribution to phyto-oestrogen intake $-40 \cdot 8 \%$ and $35 \cdot 6 \%$, respectively. In soya consumers, vegetable dishes and soya/goat's/ sheep's milks were the main contributors $-45 \cdot 7 \%$ and $21 \cdot 3 \%$ in men and $38.4 \%$ and $33.7 \%$ in women, respectively.

Conclusions: The ability to estimate phyto-oestrogen intake in Western populations more accurately will aid investigations into their suggested effects on health.
\end{abstract}

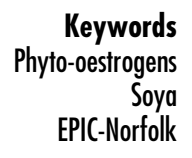

Phyto-oestrogens are a group of non-steroidal, polyphenolic plant metabolites that induce biological responses and can mimic or modulate the action of endogenous oestrogens, often by binding to oestrogen receptors ${ }^{(1)}$. The bioactivity of phyto-oestrogens is based on their structural similarity to $17 \beta$-oestradiol ${ }^{(2)}$ and their ability to bind to the oestrogen receptor ${ }^{(3)}$. Due to their bioactivity, these compounds are associated with potentially beneficial effects on a wide range of human conditions, such as cancer ${ }^{(4-6)}$, $\operatorname{CVD}^{(7,8)}$, osteoporosis ${ }^{(9)}$, menopausal symptoms ${ }^{(10,11)}$, obesity and type 2 diabetes ${ }^{(12,13)}$. The occurrence of many of these conditions is much lower in traditional Asian societies, where phyto-oestrogen-rich foods form an important component of the diet. Estimates suggest that the average isoflavone intake in Japan ranges from 25 to $100 \mathrm{mg} / \mathrm{d}^{(1)}$. 
The major phyto-oestrogen classes are isoflavones, found predominantly in legumes and soya foods; lignans, found in cereals, linseed, fruits and vegetables; and coumestans, found in young sprouting legumes, such as clover and alfalfa sprouts. Colonic microflora metabolise plant lignans into enterolignans, enterolactone and enterodiol $^{(14)}$. Daidzein, an isoflavone, is metabolised to equol in some individuals ${ }^{(15)}$. Traditional soya foods rich in isoflavones, such as tofu, tempeh and miso, are seldom consumed in the UK; instead soya dairy alternatives, such as soya milk, cheese, yoghurts, and textured vegetable protein (TVP)/tofu burgers are more commonly eaten. However a number of commercial products, such as bread, biscuits and breakfast cereals, contain soya ingredients as food additives and these also contribute to phyto-oestrogen intake ${ }^{(16,17)}$.

A number of detailed studies have previously been carried out to measure the phyto-oestrogen content of food items in the $\mathrm{UK}^{(18-20)}$, Finland ${ }^{(21)}$, the $\mathrm{USA}^{(17,22)}$, the Netherlands ${ }^{(23)}$ and Canada ${ }^{(24)}$. To date, there are few data available on soya and/or phyto-oestrogen intakes in the UK and most intake data have been mainly on isoflavones.

The present paper investigates the intakes, distributions and sources of phyto-oestrogen-containing foods in a population-based cohort study, the Norfolk arm of the European Prospective Investigation into Cancer and Nutrition (EPIC-Norfolk), as recorded by a $7 \mathrm{~d}$ food diary (7dFD), using a newly in-filled phyto-oestrogen database.

\section{Methods}

\section{The EPIC-Norfolk study}

EPIC-Norfolk is a prospective cohort study of over 25000 free-living men and women, aged between 40 and 75 years, studying the effects of nutrition and other lifestyle factors on health ${ }^{(25)}$. The study was approved by the Norwich District Health Authority Ethics Committee, and all participants gave signed informed consent. Participants completed a 7dFD between 1993 and 1998, of which 92\% were returned. Of these, 20437 were entered and available for statistical analysis.

\section{Dietary data}

The 7dFD is an A5, 45-page booklet in which the description, preparation and amounts of foods and drinks consumed at main meals, snacks and between meals are recorded over a week ${ }^{(26)}$. A trained nurse instructed each participant on how to fill in the diary. As part of this instruction, the nurse asked the participant to recall the previous day's intake and this description was written into the first day.

The diary data were entered using DINER (Data Into Nutrients for Epidemiological Research), a data-entry system specifically created for EPIC-Norfolk ${ }^{(27)}$. The DINER program contains nutrient data derived from the 5 th edition of McCance and Widdowson's The Composition of Foods and associated supplements ${ }^{(28-37)}$. Although there are approximately 4500 food items available from these sources, the nutrient data of only 2704 of these food items are appropriate as DINER only contains foods in an edible state. More than 8000 items, so-called 'new foods', have been added to DINER in an attempt to cover the wide range of foods and drinks available in the UK. The nutrient data of these 'new foods' is obtained by matching known nutrient composition, e.g. using manufacturers' data, with between one and four of the aforementioned 2704 items, in order to obtain the best possible match of nutrient analyses. These 'new foods' also contain approximately 2300 non-specific (n.s.) items, which are used when the data recorded in a food diary are minimal or missing, e.g. 'bread n.s.', 'milk n.s.', etc.

\section{Selection of foods for analysis}

Primarily single food items, called 'basic foods', were chosen for analysis (e.g. banana, rice, flour, peas). Foods to be analysed were selected on the basis of their frequency of consumption, calculated from the entry of more than 14500 7dFD from EPIC-Norfolk. However, soya-containing foods (e.g. soya mince, soya and linseed bread) were also analysed, in addition to foods previously thought not to contain any phyto-oestrogens (e.g. meat, fish) and foods where there was uncertainty regarding the presence of phyto-oestrogens (e.g. milk, tea, coffee, alcohol). Of the 2704 foods, 349 were analysed for phyto-oestrogen content (13\%); values have been reported for cereals and cereal-based foods $^{(38)}$, fruits and vegetables ${ }^{(39)}$, beverages, nuts, seeds and oils ${ }^{(40)}$ and foods from animal origin ${ }^{(41)}$.

\section{Analysis of foods}

The phyto-oestrogens analysed included the isoflavones: biochanin A, daidzein, genistein, glycitein and formononetin; the lignans: matairesinol, secoisolariciresinol and shonanin; the enterolignans: enterodiol and enterolactone; and equol and coumestrol. Foods were analysed as described previously ${ }^{(42)}$. In brief, foods were prepared, freezedried and extracted with $10 \%$ aqueous methanol by volume. After deconjugation with Helix pomatia juice, samples were prepared by solid-phase extraction and analysed by LC-MS/MS with triply ${ }^{13} \mathrm{C}$-labelled internal standards. The reproducibility of this method is better than $15 \%$ (relative CV) and the detection limit is $1.5 \mu \mathrm{g} / 100 \mathrm{~g}$.

\section{Development of the phyto-oestrogen database}

The remaining basic foods were in-filled using one of three methods: copying, calculating using a conversion factor or calculating using a recipe.

Values from similar food items were copied and assigned to 295 basic foods (11\%). Copying of values was carried out: (i) where there were two or more foods of a similar classification, but the analysis for only one of these was available (e.g. analysis of roast chicken breast used 
for grilled chicken breast without skin, fresh lemon juice used for fresh lime juice); (ii) where commercial products were analysed but similar types were not (e.g. analysis of commercial trifle used for frozen commercial trifle and frozen, boiled petit pois used for canned petit pois); and (iii) where recipe foods needed to be calculated without the availability of a recipe (e.g. values of homemade mayonnaise used for commercial mayonnaise, fresh chocolate éclair used for frozen chocolate éclair).

The foods that were analysed contained the edible part only. Therefore foods that included skin, bone/fat and peel had to be calculated accordingly, as did foods where the phyto-oestrogen content changed due to water uptake during cooking or water loss during drying. Values for 175 basic food items were calculated using a conversion factor in this way (6.5\%). Examples include toasted brown bread and avocado weighed with skin and stone.

Only a limited number of meats were analysed so values for other meats had to be in-filled from these data, many of which were calculated from separately analysed lean and fat samples. For example, 'beef, topside, roasted, well done, lean and fat' was calculated using the analysed values of 'beef, topside, roasted, well done, lean' (87\%) and 'beef fat, roasted' (13\%).

Of the aforementioned 2704 foods, 1056 had their phyto-oestrogen content assigned using the recipe calculation method (39\%), using basic food analyses and recipes mainly available in the 5th edition of McCance and Widdowson's The Composition of Foods and associated supplements ${ }^{(28-37)}$. Examples of recipe foods include vegetable lasagne, egg custard tart and banana cake.

Remaining foods had different types of missing value assigned. The phyto-oestrogen content was assumed zero (e.g. salt, water); or amount unknown but may be significant (e.g. cocoa/hot chocolate powders, some cheeses, herbs and spices, less commonly consumed fruits and vegetables, some fish, some fats and oils, some meats, chocolate and savoury snacks).

\section{Categorisation of soya foods and consumers}

In the DINER system, similar foods are grouped together, such as tea and coffee, fruits, vegetables, breakfast cereals, etc. These food groups have been utilised to study food group sources of total lignans, total isoflavones and total phyto-oestrogens between 'soya consumers' (SC) and 'nonsoya consumers' (NSC). SC were identified as those who had consumed any foods related to 'soya', 'tofu', 'TVP', 'tempeh' and/or 'miso', of which there were 134 in the DINER program. NSC did not consume any of these foods.

\section{Statistical analyses}

The data were analysed using the statistical software packages SAS version 9 and STATA version 10. Mean, standard deviation, median and interquartile range (IQR) were calculated to describe the distribution of intakes for two groups: SC and NSC, stratified by sex. Differences in means between these groups were tested using two-sided $t$ tests and further adjusted for energy intake using linear regression analyses.

\section{Results}

\section{Absolute phyto-oestrogen intake}

Table 1 describes anthropometric data and average daily coumestrol, total enterolignan, isoflavone, lignan, phytooestrogen and energy intakes in 9326 NSC men and 354 SC men. The mean daily intakes of total isoflavones $(P<0 \cdot 0001)$, lignans $(P<0 \cdot 001)$ and phyto-oestrogens $(P<0 \cdot 0001)$ were significantly higher in SC men than in NSC men; mean daily total phyto-oestrogen intake was 5051 (SD 5031) $\mu \mathrm{g}$ in SC men but only 1369 (SD 942) $\mu \mathrm{g}$ in NSC men. NSC men were significantly older and heavier and had a significantly greater BMI (all $P<0 \cdot 05$ ).

Data for 10274 NSC and 483 SC women are shown in Table 2. The mean daily intakes of total isoflavones, lignans and phyto-oestrogens (all $P<0 \cdot 0001$ ) were significantly

Table 1 Average daily intakes of coumestrol, total enterolignans, total isoflavones, total lignans, total phyto-oestrogens and energy in nonsoya-consuming (NSC) men ( $n$ 9326) and soya-consuming (SC) men ( $n$ 354), as measured by a $7 \mathrm{~d}$ food diary, and anthropometric data. Men aged 40-79 years, Norfolk arm of the European Prospective Investigation into Cancer and Nutrition (EPIC-Norfolk), 1993-1997

\begin{tabular}{|c|c|c|c|c|c|c|c|c|c|c|c|}
\hline \multirow[b]{2}{*}{ Variable } & \multicolumn{4}{|c|}{ NSC men ( $n$ 9326) } & \multicolumn{4}{|c|}{ SC men (n 354) } & \multirow[b]{2}{*}{ MD } & \multirow[b]{2}{*}{$\mathrm{Cl}$ of $\mathrm{MD}$} & \multirow[b]{2}{*}{$P$ value } \\
\hline & Mean & SD & Median & IQR & Mean & SD & Median & IQR & & & \\
\hline Coumestrol $(\mu \mathrm{g})$ & 7 & 9 & 5 & $4-8$ & 8 & 7 & 6 & $4-9$ & -0.5 & $-1 \cdot 2,0 \cdot 3$ & 0.25 \\
\hline Total enterolignans $(\mu \mathrm{g})$ & 19 & 9 & 18 & $13-24$ & 18 & 9 & 17 & $12-24$ & 0.9 & $-0 \cdot 1,1 \cdot 8$ & 0.07 \\
\hline Total isoflavones $(\mu \mathrm{g})$ & 1033 & 871 & 858 & $633-1155$ & 4664 & 4973 & 2413 & $998-6845$ & -3631 & $-4152,-3111$ & $<0.0001$ \\
\hline Total lignans $(\mu \mathrm{g})$ & 311 & 178 & 273 & $209-364$ & 361 & 230 & 309 & $237-422$ & -50 & $-75,-26$ & $<0.001$ \\
\hline Total phyto-oestrogens $(\mu \mathrm{g})$ & 1369 & 942 & 1185 & $926-1502$ & 5051 & 5031 & 2861 & $1304-7269$ & -3681 & $-4208,-3155$ & $<0.0001$ \\
\hline Energy (kJ) & 9366 & 2206 & 9283 & $7878-10717$ & 9417 & 2042 & 9275 & 8004-10 653 & -50 & $-268,168$ & 0.65 \\
\hline Age (years) & $61 \cdot 1$ & $9 \cdot 0$ & $61 \cdot 8$ & $53 \cdot 6-68 \cdot 7$ & $59 \cdot 7$ & $9 \cdot 3$ & $59 \cdot 6$ & $51 \cdot 9-67 \cdot 7$ & $1 \cdot 4$ & $0 \cdot 4,2 \cdot 4$ & $<0.05$ \\
\hline Weight $(\mathrm{kg})^{*}$ & $80 \cdot 4$ & $11 \cdot 5$ & $79 \cdot 4$ & $72 \cdot 8-87 \cdot 2$ & $78 \cdot 4$ & $11 \cdot 3$ & $77 \cdot 9$ & $70 \cdot 8-84 \cdot 8$ & 1.9 & $0 \cdot 7,3 \cdot 1$ & $<0.005$ \\
\hline Height $(\mathrm{cm})+$ & $173 \cdot 7$ & $6 \cdot 6$ & $173 \cdot 7$ & $169 \cdot 3-178 \cdot 1$ & $173 \cdot 7$ & $6 \cdot 3$ & $173 \cdot 8$ & $169 \cdot 1-177 \cdot 8$ & $0 \cdot 0$ & $-0 \cdot 6,0 \cdot 7$ & 0.96 \\
\hline BMI $\left(\mathrm{kg} / \mathrm{m}^{2}\right) \ddagger$ & $26 \cdot 6$ & $3 \cdot 3$ & $26 \cdot 3$ & $24 \cdot 4-28 \cdot 5$ & $26 \cdot 0$ & $3 \cdot 3$ & $25 \cdot 7$ & $23 \cdot 9-27 \cdot 8$ & 0.6 & $0 \cdot 3,1 \cdot 0$ & $<0.001$ \\
\hline
\end{tabular}

IQR, interquartile range; MD, difference between means

${ }^{*} \mathrm{NSC}$ men $(n$ 9320).

tNSC men ( $n$ 9315).

‡NSC men ( $n$ 9311). 
Table 2 Average daily intakes of coumestrol, total enterolignans, total isoflavones, total lignans, total phyto-oestrogens and energy in nonsoya-consuming (NSC) women ( $n 10274$ ) and soya-consuming (SC) women ( $n 483$ ), as measured by a $7 \mathrm{~d}$ food diary, and anthropometric data. Women aged 40-79 years, Norfolk arm of the European Prospective Investigation into Cancer and Nutrition (EPIC-Norfolk), 1993-1997

\begin{tabular}{|c|c|c|c|c|c|c|c|c|c|c|c|}
\hline \multirow[b]{2}{*}{ Variable } & \multicolumn{4}{|c|}{ NSC women ( $n 10$ 274) } & \multicolumn{4}{|c|}{ SC women ( $n$ 483) } & \multirow[b]{2}{*}{ MD } & \multirow[b]{2}{*}{$\mathrm{Cl}$ of $\mathrm{MD}$} & \multirow[b]{2}{*}{$P$ value } \\
\hline & Mean & SD & Median & IQR & Mean & SD & Median & IQR & & & \\
\hline Coumestrol $(\mu \mathrm{g})$ & 6 & 8 & 5 & $3-7$ & 7 & 10 & 5 & $4-8$ & $-1 \cdot 0$ & $-1 \cdot 9,-0 \cdot 1$ & 0.02 \\
\hline Total enterolignans $(\mu \mathrm{g})$ & 16 & 8 & 16 & $11-21$ & 16 & 8 & 15 & $10-20$ & 0.9 & $0 \cdot 2,1 \cdot 6$ & 0.02 \\
\hline Total isoflavones $(\mu \mathrm{g})$ & 734 & 597 & 615 & $457-819$ & 5055 & 6054 & 2830 & $779-6938$ & -4322 & $-4863,-3780$ & $<0.0001$ \\
\hline Total lignans $(\mu \mathrm{g})$ & 251 & 141 & 229 & $180-293$ & 318 & 212 & 276 & $215-351$ & -67 & $-86,-48$ & $<0.0001$ \\
\hline Total phyto-oestrogens $(\mu \mathrm{g})$ & 1008 & 652 & 877 & $703-1105$ & 5396 & 6092 & 3142 & $1089-7327$ & -4389 & $-4934,-3844$ & $<0.0001$ \\
\hline Energy (kJ) & 7100 & 1649 & 7076 & $5961-8128$ & 7443 & 1635 & 7422 & $6291-8568$ & -344 & $-493,-194$ & $<0.0001$ \\
\hline Age (years) & $60 \cdot 4$ & $9 \cdot 3$ & $60 \cdot 7$ & $52 \cdot 3-68 \cdot 3$ & $57 \cdot 9$ & $9 \cdot 0$ & $57 \cdot 4$ & $50 \cdot 2-64 \cdot 9$ & $2 \cdot 5$ & $1 \cdot 7,3 \cdot 4$ & $<0.0001$ \\
\hline Weight $(\mathrm{kg})^{\star}$ & $68 \cdot 2$ & $11 \cdot 9$ & $66 \cdot 6$ & $60 \cdot 0-74 \cdot 4$ & $65 \cdot 1$ & $10 \cdot 6$ & $63 \cdot 0$ & $58 \cdot 0-70 \cdot 8$ & $3 \cdot 1$ & $2 \cdot 2,4 \cdot 1$ & $<0.0001$ \\
\hline Height $(\mathrm{cm}) \dagger$ & $160 \cdot 7$ & $6 \cdot 2$ & $160 \cdot 7$ & $156 \cdot 6-164 \cdot 9$ & $161 \cdot 8$ & $6 \cdot 8$ & $161 \cdot 2$ & $157 \cdot 6-166 \cdot 2$ & $-1 \cdot 1$ & $-1 \cdot 7,-0.5$ & $<0.001$ \\
\hline BMI $\left(\mathrm{kg} / \mathrm{m}^{2}\right) \ddagger$ & $26 \cdot 4$ & $4 \cdot 4$ & $25 \cdot 7$ & $23 \cdot 4-28 \cdot 7$ & $24 \cdot 8$ & $3 \cdot 8$ & $24 \cdot 1$ & $22 \cdot 2-26 \cdot 9$ & $1 \cdot 6$ & $1 \cdot 2,1 \cdot 9$ & $<0.0001$ \\
\hline
\end{tabular}

IQR, interquartile range; MD, difference between means.

${ }^{*} \mathrm{NSC}$ women ( $\left.n 10256\right)$; SC women ( $n$ 482).

+NSC women (n 10255$)$; SC women (n 482).

fNSC women ( $n 10247$ ); SC women ( $n$ 482).

higher in SC women than in NSC women; mean daily total phyto-oestrogen intake was 5396 (sD 6092) $\mu \mathrm{g}$ in SC women but only 1008 (SD 652) $\mu \mathrm{g}$ in NSC women. NSC women consumed significantly less energy than SC women $(P<0 \cdot 0001)$. However, the results from the energy-adjusted means did not differ from the unadjusted means. SC women were significantly younger, lighter and taller, and therefore also had a significantly lower BMI $(P<0 \cdot 0001$ for all except height, where $P<0 \cdot 001$ ).

The mean daily total phyto-oestrogen intake was higher in SC women than in SC men, $5396 \mu \mathrm{g} v .5051 \mu \mathrm{g}$, but this difference was not significant. However, average daily intakes of total lignans $(P<0.05)$ and total enterolignans $(P<0.001)$ were significantly higher in SC men than in SC women.

The intakes of coumestrol, total enterolignans, isoflavones, lignans and phyto-oestrogens were slightly higher in all men than in all women and these differences were significant $(P<0 \cdot 0001)$. The mean total daily phytooestrogen intake was $1504 \mu \mathrm{g}$ in men (SD $1502 \mu \mathrm{g}$; median $1199 \mu \mathrm{g}$, IQR $934-1537 \mu \mathrm{g}$ ) and $1205 \mu \mathrm{g}$ in women (SD $1701 \mu \mathrm{g}$; median $888 \mu \mathrm{g}$, IQR 710-1135 $\mu \mathrm{g}$; data not shown). Total enterolignan intake was low in both men and women and was significantly related to milk and milk products intake $(P<0 \cdot 0001)$.

Table 3 illustrates total mean daily phyto-oestrogen intake, by 10-year age bands, for NSC and SC, stratified by sex. There was a small significant linear decrease $(P<0 \cdot 0001)$ in intake for both NSC men and women, as well as for SC men, with increasing age; this linear decrease was not as significant in SC women $(P<0 \cdot 05)$. When the data were adjusted for energy, similar trends were observed (Table 3).

\section{Sources of phyto-oestrogen intake}

Data on percentage food group sources of total phytooestrogens, total isoflavones and total lignans in men and women are shown in Table 4, but only where food groups contribute $5 \%$ or more to the intake of each phyto-oestrogen group. In all men and women, bread and bread rolls made the greatest contribution to phytooestrogen intake $-40 \cdot 8 \%$ and $35 \cdot 6 \%$, respectively. When SC were excluded, the contribution made by bread and bread rolls rose to $45 \cdot 1 \%$ in men and $42.4 \%$ in women. However, in SC men and women, foods contributing to total phyto-oestrogen intake were very different, with vegetable dishes and soya/goat's/sheep's milk being the main contributors, accounting for a combined total of approximately $67 \%$ of intake in men and $72 \%$ in women.

Bread and bread rolls also made the greatest contribution to total isoflavone intake in all men and women $-51.3 \%$ and $45.2 \%$, respectively. In SC, vegetable dishes and soya/goat's/sheep's milk were the main contributors, accounting for approximately $66 \%$ of intake in men and $72 \%$ in women.

Tea and coffee were the main contributors to total lignan intakes, accounting for $32 \cdot 8 \%$ of intake in men and $37 \cdot 3 \%$ in women. These values are very similar to those found in NSC men and women $(33.0 \%$ and $37 \cdot 8 \%$, respectively). This food group was also the greatest contributor to lignan intake in SC: $26.9 \%$ in men and $29 \cdot 4 \%$ in women. The consumption of alcohol also contributed to lignan intake: approximately $7 \%$ of intake in all women from wine and $21 \%$ in all men from wine, beer and lager.

Figure 1a illustrates the percentage contribution of food groups to the daily intake of total phyto-oestrogens in NSC. Bread and bread rolls made the greatest contribution ( $43 \%)$, followed by breakfast cereals (12\%) and tea and coffee (6\%). In SC, vegetable dishes were the highest contributor (41\%), followed by soya/goat's/sheep's milk (25\%) and bread and bread rolls (11\%) (Fig. 1b).

\section{Food choices of soya consumers and non-soya consumers}

Mean average daily intakes (in grams) of the food groups listed in Table 4 were compared between SC and NSC, stratified by sex, using a two-sample $t$ test. In men, these 


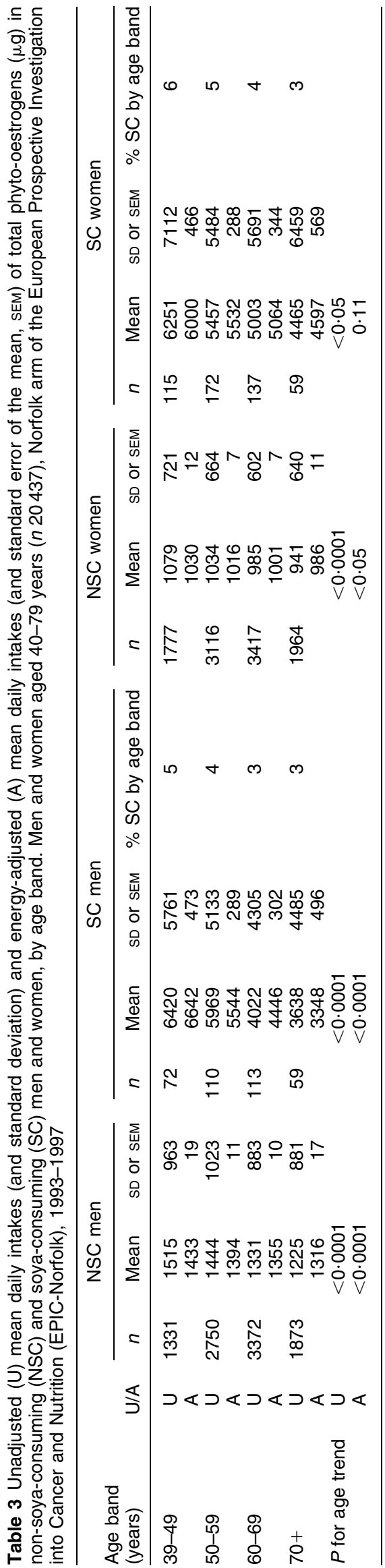

were all significantly different $(P<0 \cdot 0001$ for all food groups except wine, where $P<0 \cdot 05)$. NSC men had significantly higher intakes of vegetables, fruits, nuts and seeds, meat products, wine and beer and lager; intakes of bread and bread rolls, breakfast cereals, tea and coffee, vegetable dishes and soya/goat's/sheep's milk were higher in SC men.

In women, mean average daily intakes of most food groups listed were significantly different between SC and NSC $(P<0.0001$ for all food groups, with the exception of wine and soya/goat's/sheep's milk where $P<0.05$ ). NSC women had significantly higher intakes of vegetables, fruits, nuts and seeds, meat products, soya/goat's/ sheep's milk and beer and lager; intakes of bread and bread rolls, breakfast cereals, tea and coffee, wine and vegetable dishes were higher in SC women.

\section{Discussion}

The aim of the present study was to investigate the average intake and distribution of soya-containing foods, coumestrol, total isoflavones, lignans, enterolignans and phytooestrogens, using a newly in-filled phyto-oestrogen database. This data set of phyto-oestrogen intake data is one of the largest to be investigated to date. The isoflavone intake data are similar to the intake of the vegetarian group $(7 \cdot 4 \mathrm{mg} / \mathrm{d})$ in a recent UK study ${ }^{(43)}$. Data from the 1998 UK Total Diet Study estimated average daily intake of $3 \mathrm{mg}$ of the combined isoflavone aglycones (daidzein, genistein and glycitein) ${ }^{(44)}$. Exposure estimates of total isoflavones for SC and soya-containing foods in UK adults based on the National Diet and Nutrition Survey (1986-1987) and the Dietary Survey of Vegetarians (1994-1995) were 0.6 and $2.6 \mathrm{mg} /$ person per $\mathrm{d}$ respectively ${ }^{(45)}$.

These data on daily isoflavone intake are higher than those from a previous study of EPIC-Norfolk participants ${ }^{(46)} ; 0 \cdot 84 \mathrm{mg}$ in all men (IQR $0 \cdot 39-0 \cdot 82 \mathrm{mg}$ ) and $0.77 \mathrm{mg}$ in all women (IQR $0.30-0.64 \mathrm{mg}$ ). The differences in intake can mainly be attributed to the inclusion of the phyto-oestrogen analysis of certain foods in the database, foods which had not previously been analysed in the UK, such as tea, coffee, meat, fish, milk and dairy products $^{(40,41)}$, as well as changes in the isoflavone content of isoflavone-rich foods, such as soya flour, soya yoghurt, tofu/soyabean curd, tofu burgers and soyabean burgers. These foods were previously taken from published values ${ }^{(47)}$ but recently analysed in the $\mathrm{UK}^{(38,41)}$ and a $30-85 \%$ reduction in their isoflavone content was found. Some commonly consumed foods, including brown and wholemeal breads, were also found to contain $20-30 \%$ less isoflavones than previously estimated. The phyto-oestrogen content in plants is variable and depends on genetic, environmental, growth, harvesting and processing factors. A recent investigation into the variability of the phyto-oestrogen content in nine foods from different sources has shown that the phyto-oestrogen 
Table 4 Percentage (\%) contribution to total phyto-oestrogens (TOT PE), total isoflavones (TOT ISO) and total lignans (TOT LIG) from food groups, in all men and women, and non-soya-consuming (NSC) and soya-consuming (SC) men and women, ordered by percentage contribution in all men. Men and women aged 40-79 years ( $n 20$ 437), Norfolk arm of the European Prospective Investigation into Cancer and Nutrition (EPIC-Norfolk), 1993-1997

\begin{tabular}{|c|c|c|c|c|c|c|c|}
\hline Food group & PE group & All men & NSC men & SC men & All women & NSC women & SC womer \\
\hline \multirow[t]{3}{*}{ Bread and bread rolls* } & TOT PE & $40 \cdot 8$ & $45 \cdot 1$ & $9 \cdot 5$ & $35 \cdot 6$ & $42 \cdot 4$ & $6 \cdot 8$ \\
\hline & TOT ISO & $51 \cdot 3$ & $58 \cdot 0$ & 13.9 & $45 \cdot 2$ & $56 \cdot 7$ & $9 \cdot 9$ \\
\hline & TOT LIG & - & - & $5 \cdot 5$ & - & - & $6 \cdot 0$ \\
\hline \multirow[t]{3}{*}{ Breakfast cereals* } & TOT PE & $11 \cdot 3$ & $12 \cdot 0$ & $6 \cdot 2$ & $10 \cdot 3$ & $11 \cdot 2$ & $6 \cdot 3$ \\
\hline & TOT ISO & $13 \cdot 2$ & $14 \cdot 5$ & $6 \cdot 3$ & $11 \cdot 6$ & $13 \cdot 2$ & $6 \cdot 7$ \\
\hline & TOT LIG & $5 \cdot 8$ & $5 \cdot 7$ & $8 \cdot 0$ & $5 \cdot 3$ & $5 \cdot 2$ & $6 \cdot 7$ \\
\hline \multirow[t]{3}{*}{ Tea and coffee } & TOT PE & $8 \cdot 7$ & $9 \cdot 6$ & $1 \cdot 7$ & $10 \cdot 2$ & $12 \cdot 2$ & $1 \cdot 7$ \\
\hline & TOT ISO & - & - & - & - & - & - \\
\hline & TOT LIG & $32 \cdot 8$ & $33 \cdot 0$ & $26 \cdot 9$ & $37 \cdot 3$ & $37 \cdot 8$ & $29 \cdot 4$ \\
\hline \multirow[t]{3}{*}{ Vegetable dishes* } & TOT PE & $7 \cdot 5$ & $2 \cdot 3$ & $45 \cdot 7$ & $9 \cdot 6$ & $2 \cdot 8$ & $38 \cdot 4$ \\
\hline & TOT ISO & $9 \cdot 3$ & - & $45 \cdot 7$ & $12 \cdot 7$ & - & $41 \cdot 0$ \\
\hline & TOT LIG & - & - & $5 \cdot 8$ & - & - & $6 \cdot 0$ \\
\hline \multirow[t]{3}{*}{ Meat products } & TOT PE & $5 \cdot 0$ & $5 \cdot 5$ & 0.6 & 3.9 & $4 \cdot 8$ & - \\
\hline & TOT ISO & $6 \cdot 3$ & $7 \cdot 3$ & - & $5 \cdot 0$ & $6 \cdot 5$ & - \\
\hline & TOT LIG & - & - & - & - & - & - \\
\hline \multirow[t]{3}{*}{ Milk, soya/goat's/sheep's* } & TOT PE & $2 \cdot 5$ & - & $21 \cdot 3$ & $6 \cdot 4$ & - & $33 \cdot 7$ \\
\hline & TOT ISO & - & - & $20 \cdot 5$ & $7 \cdot 7$ & - & $31 \cdot 1$ \\
\hline & TOT LIG & - & - & - & - & - & - \\
\hline \multirow[t]{3}{*}{ Beer and lager } & TOT PE & - & - & - & - & - & - \\
\hline & TOT ISO & - & - & - & - & - & - \\
\hline & TOT LIG & $12 \cdot 1$ & $12 \cdot 3$ & $8 \cdot 8$ & - & - & - \\
\hline \multirow[t]{3}{*}{ Vegetables } & TOT PE & - & - & - & - & - & - \\
\hline & TOT ISO & - & - & - & - & - & - \\
\hline & TOT LIG & $9 \cdot 4$ & $9 \cdot 5$ & $8 \cdot 4$ & $11 \cdot 7$ & $11 \cdot 7$ & $11 \cdot 3$ \\
\hline \multirow{3}{*}{ Wine } & TOT PE & - & - & - & - & - & - \\
\hline & TOT ISO & - & - & - & - & - & - \\
\hline & TOT LIG & 8.9 & 8.9 & $8 \cdot 3$ & $7 \cdot 3$ & $7 \cdot 4$ & $7 \cdot 0$ \\
\hline \multirow[t]{3}{*}{ Fruits } & TOT PE & - & - & - & - & - & - \\
\hline & TOT ISO & - & - & - & - & - & - \\
\hline & TOT LIG & $5 \cdot 4$ & $5 \cdot 3$ & $7 \cdot 3$ & $9 \cdot 1$ & $9 \cdot 1$ & $10 \cdot 3$ \\
\hline \multirow[t]{3}{*}{ Nuts and seeds* } & TOT PE & - & - & - & - & - & - \\
\hline & TOT ISO & - & - & - & - & - & - \\
\hline & TOT LIG & - & - & - & - & - & $6 \cdot 0$ \\
\hline
\end{tabular}

,$- \%$ contribution $<5.0 \%$.

${ }^{*}$ Contain soya/textured vegetable protein/tofu/tempeh foods.

content varied on average by a factor of $2 \cdot 8$, with a $\mathrm{CV}$ of $39 \%$ for isoflavones and $33 \%$ for lignans ${ }^{(48)}$.

Food group sources of total lignans, total isoflavones and total phyto-oestrogens were analysed separately. The richest food group source of both total isoflavones and phyto-oestrogens was bread and bread rolls. This is due to the soya flour added to bread in largescale bread manufacture which produces $80 \%$ of the UK's bread. In EPIC-Norfolk, 96-97\% of bread is commercially produced. Data from Italy and Ireland have estimated that over $90 \%$ of total isoflavone intake comes from bread ${ }^{(49)}$

Recipes from McCance and Widdowson's The Composition of Foods, 5th edition and its associated food supplements ${ }^{(28-37)}$ were used in calculating the phytooestrogen content of most food products and dishes. However, some of these foods were analysed in the 1980s (e.g. croissants, jam tarts, scones, apple pies), and soya is not listed as an ingredient. In the DINER system ${ }^{(27)}$, commercial items sometimes receive the same nutrient composition as homemade items in the absence of reliable analyses. Therefore underestimation of phyto-oestrogen content is likely as it has been estimated that $60 \%$ of commercially processed foods contain soya ${ }^{(17)}$.

Regarding food group sources of phyto-oestrogens in SC, vegetable dishes and soya/goat's/sheep's milk were the main contributors. Soya product consumption in ten countries participating in the EPIC study consisting of 35955 subjects, as measured by a $24 \mathrm{~h}$ dietary recall interview, found that soya product consumption is low in Western European countries. Of the seven subgroups of soya products, soya dairy products were consumed in the highest quantities: $1200 \mathrm{mg} / \mathrm{d}$ for men and $1900 \mathrm{mg} / \mathrm{d}$ for women ${ }^{(50)}$.

A number of the findings relating to the food group choices made by SC and NSC were somewhat unexpected. In both NSC men and women, intakes of vegetables, fruit, nuts and seeds were significantly higher, whereas intakes of bread and bread rolls, breakfast cereals, tea and coffee and vegetable dishes were significantly higher in SC. However the differences found were small and could have been due to the large sample size. A more detailed food group classification is required to more accurately assess choices made by SC and NSC. 
(a)

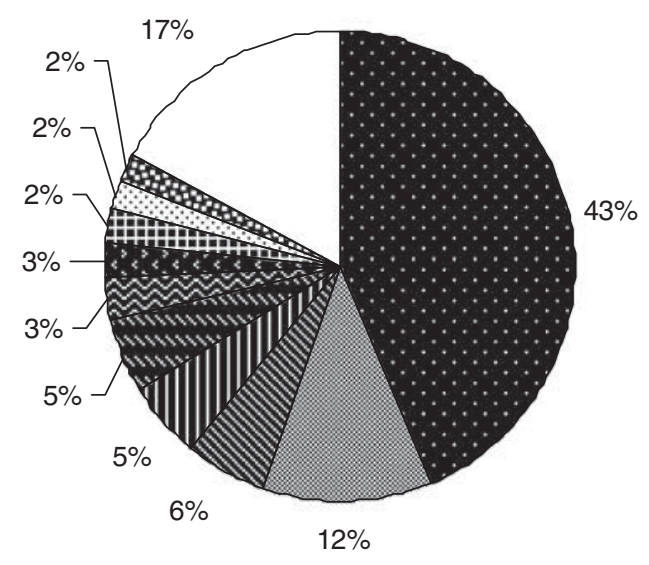

(b)

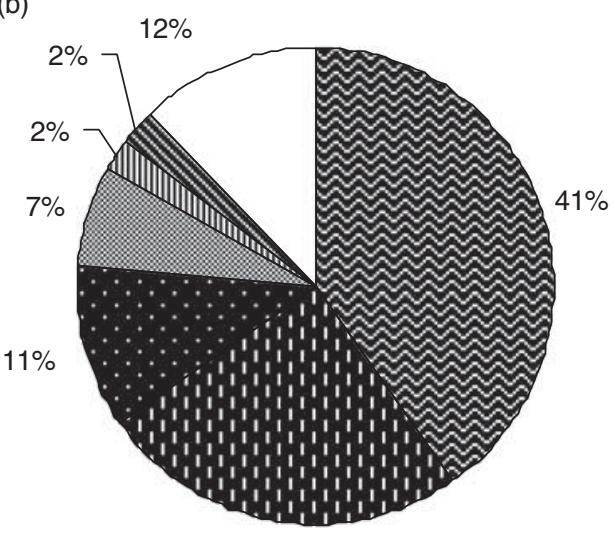

Bread \& bread rolls

Breakfast cereals

Tea \& coffee

II Meat products

ऽ Vegetables

因 Vegetable dishes

a Fruits

\# Beer and lager

回 Wine

图 Milk and milk products

Other

$25 \%$

\begin{tabular}{|l|}
\hline Vegetable dishes \\
Bilk, soya/goat/sheep \\
Bread \& bread rolls \\
Breakfast cereals \\
四asta, noodles and \\
couscous \\
Tea \& coffee \\
$\square$ Other
\end{tabular}

Fig 1 Percentage contribution of food groups to the daily intake of total phyto-oestrogens in (a) non-soya consumers and (b) soya consumers. Men and women aged 40-79 years (n 20 437), Norfolk arm of the European Prospective Investigation into Cancer and Nutrition (EPIC-Norfolk), 1993-1997

The ability to more accurately estimate phyto-oestrogen and soya intake in Western populations will enable investigations into the suggested beneficial effects of soya on health to be carried out, in the absence of biomarker data.

\section{Acknowledgements}

Source of funding: This study was supported by research grants from the Food Standards Agency (T05028), the Medical Research Council (G0500300, G1000143) and Cancer Research UK (C864/A8257). Conflicts of interest: The authors declare that they have no conflict of interest. Authors' contribution: A.A.M. oversaw the development of the database, conducted the statistical analyses and drafted the manuscript. M.A.H.L., K.-T.K. and G.G.C.K. assisted in writing and revising the manuscript. M.A.H.L., V.v.S., N.A.P. and A.M. assisted in the development of the database. A.B. created the programs for the database. All authors read and approved the final manuscript.
Acknowledgements: The authors would like to thank all participants of the EPIC-Norfolk study and the EPIC staff for their help with this work.

\section{References}

1. Committee on Toxicity of Chemicals in Food, Consumer Products and the Environment (2003) Phytoestrogens and Health. London: Food Standards Agency.

2. Setchell KDR \& Adlercreutz H (1988) Mammalian lignans and phytoestrogens. In The Role of the Gut Flora in Toxicity and Cancer, pp. 315-346 [IR Rowland, editor]. London: Academic Press.

3. Shutt DA \& Cox RI (1972) Steroid and phyto-oestrogen binding to sheep uterine receptors in vitro. J Endocrinol 52, 299-310.

4. Peeters PHM, Keinan-Boker L, van der Schouw YT et al. (2003) Phytoestrogens and breast cancer risk. Review of the epidemiological evidence. Breast Cancer Res Treat 77, 171-183.

5. Buck K, Zaineddin AK, Vrieling A et al. (2010) Metaanalyses of lignans and enterolignans in relation to breast cancer risk. Am J Clin Nutr 92, 141-153. 
6. Ward HA, Kuhnle GG, Mulligan AA et al. (2010) Breast, colorectal and prostate cancer risk in the European Prospective Investigation into Cancer and Nutrition-Norfolk in relation to phytoestrogen intake derived from an improved database. Am J Clin Nutr 91 , 440-448.

7. Anthony MS (2002) Phytoestrogens and cardiovascular disease: where's the meat? Arterioscler Thromb Vasc Biol 22, 1245-1247.

8. Bhupathy P, Haines CD \& Leinwand LA (2010) Influence of sex hormones and phytoestrogens on heart disease in men and women. Womens Health (Lond Engl) 6, 77-95.

9. Lagari VS \& Levis S (2010) Phytoestrogens and bone health. Curr Opin Endocrinol Diabetes Obes 17, 546-553.

10. Krebs EE, Ensrud KE, MacDonald R et al. (2004) Phytoestrogens for treatment of menopausal symptoms: a systematic review. Obstet Gynecol 104, 824-836.

11. Tousen Y, Ezaki J, Fujii Y et al. (2011) Natural S-equol decreases bone resorption in postmenopausal, nonequol-producing Japanese women: a pilot randomized, placebo-controlled trial. Menopause 18, 563-574.

12. Bhathena SJ \& Velasquez MT (2002) Beneficial role of dietary phytoestrogens in obesity and diabetes. Am J Clin Nutr 76, 1191-1201.

13. Cederroth CR, Vinciguerra M, Gjinovci A et al. (2008) Dietary phytoestrogens activate AMP-activated protein kinase with improvement in lipid and glucose metabolism. Diabetes 57, 1176-1185.

14. Borriello SP, Setchell KD, Axelson M et al. (1985) Production and metabolism of lignans by the human faecal flora. J Appl Bacteriol 58, 37-43.

15. Rowland IR, Wiseman H, Sanders TAB et al. (2000) Interindividual variation in metabolism of soy isoflavones and lignans: influence of habitual diet on equol production by the gut microflora. Nutr Cancer 36, 27-32.

16. US Department of Agriculture (2002) USDA-Iowa State University Database on the Isoflavone Content of Foods. http://www.nal.usda.gov/fnic/foodcomp/Data/isoflav/isoflav. html (accessed November 2010).

17. the ENDS report (1996) Supermarkets demand segregation of genetically modified soya. ENDS Report issue 258, 26.

18. Liggins J, Bluck LJ, Runswick S et al. (2000) Daidzein and genistein contents of vegetables. Br J Nutr 84, 717-725.

19. Liggins J, Bluck LJ, Runswick S et al. (2000) Daidzein and genistein content of fruits and nuts. J Nutr Biochem 11, 326-331.

20. Liggins J, Mulligan A, Runswick S et al. (2002) Daidzein and genistein content of cereals. Eur J Clin Nutr 56, 961-966.

21. Valsta LM, Kilkkinen A, Mazur W et al. (2003) Phytooestrogen database of foods and average intake in Finland. Br J Nutr 89, Suppl. 1, S31-S38.

22. Horn-Ross PL, Barnes S, Lee M et al. (2000) Assessing phytoestrogen exposure in epidemiologic studies: development of a database (United States). Cancer Causes Control 11, 289-298.

23. Milder IEJ, Arts ICW, Van De Putte B et al. (2005) Lignan contents of Dutch plant foods: a database including lariciresinol, pinoresinol, secoisolariciresinol and matairesinol. BrJ Nutr 93, 393-402.

24. Thompson LU, Boucher BA, Liu Z et al. (2006) Phytoestrogen content of foods consumed in Canada, including isoflavones, lignans and coumestan. Nutr Cancer 54, 184-201.

25. Day N, Oakes S, Luben R et al. (1999) EPIC-Norfolk: study design and characteristics of the cohort. Br J Cancer $\mathbf{8 0}$, 95-103.

26. Bingham SA, Welch AA, McTaggart A et al. (2001) Nutritional methods in the European Prospective Investigation of Cancer in Norfolk. Public Health Nutr $\mathbf{4}, 847-858$.
27. Welch AA, McTaggart A, Mulligan AA et al. (2001) DINER (Data Into Nutrients for Epidemiological Research) - a new data-entry program for nutritional analysis in the EPICNorfolk cohort and the 7-day diary method. Public Health Nutr 4, 1253-1265.

28. Holland B, Unwin ID \& Buss DH (1988) Cereals and Cereal Products. Third Supplement to McCance and Widdowson's The Composition of Foods, 4th ed. Cambridge: Royal Society of Chemistry.

29. Holland B, Unwin ID \& Buss DH (1989) Milk Products and Eggs. Fourth Supplement to McCance and Widdowson's The Composition of Foods, 4th ed. Cambridge: Royal Society of Chemistry.

30. Holland B, Welch AA, Unwin ID et al. (1991) McCance and Widdowson's The Composition of Foods, 5th ed. Cambridge: Royal Society of Chemistry.

31. Holland B, Unwin ID \& Buss DH (1991) Vegetables, Herbs and Spices. Fifth Supplement to McCance and Widdowson's The Composition of Foods, 4th ed. Cambridge: Royal Society of Chemistry.

32. Holland B, Unwin ID \& Buss DH (1992) Fruit and Nuts. First Supplement to McCance and Widdowson's The Composition of Foods, 5th ed. Cambridge: Royal Society of Chemistry.

33. Holland B, Welch AA \& Buss DH (1992) Vegetable Dishes. Second Supplement to McCance and Widdowson's The Composition of Foods, 5th ed. Cambridge: Royal Society of Chemistry.

34. Holland B, Brown JB \& Buss DH (1993) Fish and Fish Products. Third Supplement to McCance and Widdowson's The Composition of Foods, 5th ed. Cambridge: Royal Society of Chemistry.

35. Chan W, Brown JB \& Buss DH (1994) Miscellaneous Foods. Fourth Supplement to McCance and Widdowson's The Composition of Foods, 5th ed. Cambridge: Royal Society of Chemistry.

36. Chan W, Brown J, Lee SM et al. (1995) Meat, Poultry and Game. Fifth Supplement to McCance and Widdowson's The Composition of Foods, 5th ed. Cambridge: Royal Society of Chemistry.

37. Chan W, Brown J, Church SM et al. (1996) Meat Products and Dishes. Sixth Supplement to McCance and Widdowson's The Composition of Foods, 5th ed. Cambridge: Royal Society of Chemistry.

38. Kuhnle GGC, Dell'aquila C, Aspinall SM et al. (2009) Phytoestrogen content of cereals and cereal-based foods consumed in the UK. Nutr Cancer 61, 302-309.

39. Kuhnle GG, Dell'Aquila C, Aspinall SM et al. (2009) Phytoestrogen content of fruits and vegetables commonly consumed in the UK based on LC-MS and ${ }^{13} \mathrm{C}$-labelled standards. Food Chem 116, 542-554.

40. Kuhnle GGC, Dell'Aquila C, Aspinall SM et al. (2008) Phytoestrogen content of beverages, nuts, seeds, and oils. J Agric Food Chem 56, 7311-7315.

41. Kuhnle GGC, Dell'Aquila C, Aspinall SM et al. (2008) Phytoestrogen content of foods of animal origin: dairy products, eggs, meat, fish, and seafood. J Agric Food Chem 56, 10099-10104.

42. Kuhnle GGC, Dell'Aquila C, Low YL et al. (2007) Extraction and quantification of phytoestrogens in foods using automated solid-phase extraction and LC/MS/MS. Anal Chem 79, 9234-9239.

43. Ritchie MR, Cummings JH, Morton MS et al. (2006) A newly constructed and validated isoflavone database for the assessment of total genistein and daidzein intake. Br J Nutr 95, 204-213.

44. Clarke DB \& Lloyd AS (2004) Dietary exposure estimates of isoflavones from the 1998 UK Total Diet Study. Food Addit Contam 21, 305-316.

45. Committee on Toxicity of Chemicals in Food, Consumer Products and the Environment (2001) Working Group on 
Phytoestrogen Paper PEG/2001/24: Amendment to the Isoflavone Intake Assessment. London: Food Standards Agency.

46. Mulligan AA, Welch AA, McTaggart AA et al. (2007) Intakes and sources of soya foods and isoflavones in a UK population cohort study (EPIC-Norfolk). Eur J Clin Nutr 61, 248-254.

47. Kiely M, Faughnan M, Wahala K et al. (2003) Phytooestrogen levels in foods: the design and construction of the VENUS database. BrJ Nutr 89, 19-23.
48. Kuhnle GGC, Dell'Aquilla C, Runswick SA et al. (2009) Variability of phytoestrogen content in foods from different sources. Food Chem 113, 1184-1187.

49. Van Erp-Baart MAJ, Brants HAM, Kiely M et al. (2003) Isoflavone intake in four different European countries: the VENUS approach. Br J Nutr 89, Suppl. 1, S25-S30.

50. Keinan-Boker L, Peeters PHM, Mulligan AA et al. (2002) Soy product consumption in 10 European countries: the European Prospective Investigation into Cancer and Nutrition (EPIC) study. Public Health Nutr 5, 1217-1226. 